\title{
Quality of Homestay Services towards Guest Satisfaction in Kalibukbuk Village, Buleleng Regency, Bali
}

\author{
Ni Desak Made Santi Diwyarthi ${ }^{1}$, Nyoman Gede Mas Wiartha ${ }^{2}$, Putu Diah Prabawati ${ }^{3}$, I Wayan Adi Pratama ${ }^{4}$ \\ \{ santidiwyarthi@yahoo.com $\left.{ }^{1}\right\}$
}

\begin{abstract}
Sekolah Tinggi Pariwisata Nusa Dua Bali, Jl. Dharmawangsa, Benoa, Kec. Kuta Sel., Kabupaten Badung, Bali, Indonesia $^{1234}$
\end{abstract}

\begin{abstract}
This study aims to identify data relating to the Quality of Homestay Services towards Guest Satisfaction in Kalibukbuk Village, Buleleng Regency, Bali. The sample collection method used is purposive sampling, with totally of 112 respondents. The respondents are the guests who stay at the homestay. Data collection techniques used are interviews, observation, documentation and questionnaires with Likert scale. The data analysis technique used is Structural Equation Model (SEM), as the primary data analysis method. There are five aspects measured, including Physical Form, Reliability, Responsiveness, Assurance, and Empathy in the quality of lodging services using in this research to provide quality of homestay services, that affect the level of guest satisfaction in the village of Kalibukbuk, Buleleng Regency, Bali. The results of multiple linear regression equations show the direction of each independent variable of this study on the dependent variable. $\mathrm{R}^{2}$ value of 0.730 shows that as much as 73 percent of physical form, reliability, responsiveness, assurance and empathy affect the quality of homestay services towards guest's satisfaction in the village of Kalibukbuk, Buleleng regency, Bali, while the remaining 27 percent is influenced by other variables. The significance value of $F$ is 0,000 which is less than 0.05 , then $\mathrm{HO}$ is rejected. This means that the quality of service (physical form, reliability, responsiveness, assurance and empathy) simultaneously has a significant effect on guest's satisfaction on quality of homestay services. The results showed that service quality variables consisting of physical form, reliability, responsiveness, assurance, and empathy simultaneously had an influence on guest satisfaction in quality of homestay services. Service quality variables partially have positive and significant effect on guest satisfaction in quality of homestay services in Kalibukbuk village, Buleleng Regency, Bali. This result shows that homestay having potential impact for hospitality industry. The suggestion are the stakeholders and management of homestay in Kalibukbuk have to prove competencies and good quality in hospitality industry.
\end{abstract}

Keywords: Guest Satisfaction; Quality of Homestay Services; Bali Tourism

\section{Introduction}

The number of tourist visit to Buleleng continuous to increase, especially in tourist attractions such as Gitgit Waterfalls, Hot Spring Yeh Panes, Buleleng Harbor, Lovina Beach. Almost 125.000 tourists visit Buleleng Regency in 2016. More than $5 \%$ over the previous year.

Tourist visit certainly needs adequate accommodation, attractions, amenities, transportation, such as hotel, restaurants, destinations. There are more than 300 homestay at Buleleng Regency, having cost at 250.000 to 1.000.000 rupiah. Tourists stay and having local experience daily with local people.

The 2016 data shows there are 219 hotels in Buleleng Regency, 89 are located in Buleleng District, and 52 of them are homestays with $5-10$ rooms. The hotels are offered with a price range of IDR 250,000 to IDR $1,000,000$. Homestays is prepared for tourists who want to spend days and having daily activities with locals. 
The advantage is community having interact with the tourists, and the tourist will be given opportunity to participate in activities taking place in the village.

Pre survey period at Buleleng District show there are non satisfied guest with the services provided at homestay. The reason is because they are not served optimally. There is no properly information about homestay, the guests are not introduced about environment, atmosphere, and culture from the village. Room cleanliness is not monitored regularly.

The way to find out the quality of services is to conduct an assessment using five dimensions of service quality according to Kotler, namely : tangibles (Physic, amenities, staff), reliability (ability to serve accurately), responsiveness (willingly to serve), assurance (staff's ability, hygiene and safety for the guest), emphaty (good relationship and service) [1]. Focus in this research are "Quality of Homestay Service towards Guest Satisfaction at Kalibukbuk Village, in Buleleng Regency, Bali”.

\section{Method}

This is Quantitative Research, and Sampling method used in this research is purposive sampling, with totally of 103 respondents. The respondents are the guests who stay at the homestay. Data collection techniques used are interviews, observation, documentation and questionnaires with Likert scale. The data analysis technique used is Structural Equation Model (SEM), as the primary data analysis method.

\section{Results and Disscusion}

Kotler mention five dimensions that affect quality of service, namely: tangible, reliability, responsiveness, assurance and empathy [2]. According to Irawan indicators that encourage guest satisfaction are product quality, price, service quality, emotional factors, and convenience [3]. Kotler explained "to find out the level of customer satisfaction, there are four measurement methods that need to be considered by the company, namely: Systems of complaints and suggestions, customer satisfaction survey, ghost shopping, and lost customer analysis [4]. Based on the Minister of Culture and Tourism Regulation Number: PM.86 / HK.501 / MKP / 2010, homestay is provision of accommodation in form of residential buildings that occupied by their owners, and used partly for rent by tourists to interact in the daily lives together with owner. Homestay are classified as non star hotels, small hotel with 5 to 25 rooms.

Tourist accommodation in Buleleng Regency are classified into 5 major groups, namely (1) star hotels, (2) budget hotels, (3) Lodging or homestay, (4) restaurants, and (5) bars. The number of tourist accommodation in Buleleng Regency is distributed into nine districts. Buleleng district has the most tourist accommodation, 99 tourist accommodation for totally 214 tourist accomodation all over Buleleng regency. Most of them are in Lovina area.

Community activities in an area are usually regulated in the form of applicable regulations, such as regulations or customary law (hukum adat)/ Likewise related to homestay in Buleleng Regency.

Windia \& Sudantra said, Adat law is a law that grows in Indonesia society which is in the form of legal norms that arise and grow inside and are caused by the association of human life. Balinese Adat law is a complex of norms, both in its written and unwritten forms, containing commands, permissions and prohibitions, which govern the lives of Balinese people concerning the relationship between fellow human beings, the relationship between humans and God [5].

Rahayu Dewi, Suwindia, \& Sudarsana said "By implementing ethics education in a steady, creative and dynamic to "Krama Desa" and community, a harmonious life is realized which includes the development of a whole human being devoted to Sang Hyang Widhi Wasa / Tuhan Yang Maha Esa / Parhyangan), peace with others (Pawongan), and love environmental sustainability (Palemahan) which will ultimately create harmony in the overall relationship" [6].

There is a relationship between modern and tradition, between homestay and resort, communities and religion, spiritual and high technologies. That is called understanding each other, function of symbol, myth, philosophies of life. The story proves that it is very important for someone to always be able to appreciate time, for that reason time is said to be valuable. A person who can appreciate time is an individual who has consciousness. With respect for time, it is also the same as devotional service to Ida Sanghyang Widhi Wasa, because time is the Sun which constantly moved. 
Hiroyuki, Juliawan and Sudarsana explain that tradition is carried out with a series of ceremonies, with implementation plans initited by the initiator. This means all activities at homestay show the tradition of Balinese culture as impementation plans from their culture. And this tradition is carried out with a series of ceremonies [7].

Paramitha finding results shows that tradition follows by a series of ceremonies, with implementation plans initiated by initiator. The internalization of character values through 3 stages, namely the value transformtion stage, transaction value stage, and transinternalisation value. It means when a tourist dicide to stay at homestay, they want the value will reach the same level as they want [8].

Totally responden are 103 people stayed in homestay at Kalibukbuk Village. Respondents have the characteristics of age 17 to 55 years old. The largest number of tourist stay at homestay are 36 to 45 years old, $35,71 \%$, or 35 responden. Next, 46 to 55 years old, 28,57\%, or 32 responden, and the lowest are over 55 years old, $7,1 \%$ or 8 responden. Women responden are 55 responden or $49,10 \%$, and men responden are $50,90 \%$ or 57 responden.

There are five aspects measured, including Physical Form, Reliability, Responsiveness, Assurance, and Empathy in the quality of lodging services using in this research to provide quality of homestay services, that affect the level of guest satisfaction in the village of Kalibukbuk, Buleleng Regency, Bali [2]. The results of multiple linear regression equations show the direction of each independent variable of this study on the dependent variable. $\mathrm{R}^{2}$ value of 0.730 shows that as much as 73 percent of physical form, reliability, responsiveness, assurance and empathy affect the quality of homestay services towards guest's satisfaction in the village of Kalibukbuk, Buleleng regency, Bali, while the remaining 27 percent is influenced by other variables. The significance value of $\mathrm{F}$ is 0,000 which is less than 0.05 , then $\mathrm{H} 0$ is rejected. This means that the quality of service (physical form, reliability, responsiveness, assurance and empathy) simultaneously has a significant effect on guest's satisfaction on quality of homestay services.

This is consistent with research conducted by Sulistino, Hidayati, and Agyapong which proves that service quality (physical evidence, reliability, responsiveness, assurance and empathy) has a significant affect simultaneously on customer satisfaction.

The regression coefficient value (X1) which has positive value indicates that physical form has a positive and significant effect on guest's satisfaction in the village of Kalibukbuk, Buleleng regency, Bali. The regression coefficient value (X2) which has positive value indicates that reliability has a positive and significant effect on guest's satisfaction in the village of Kalibukbuk, Buleleng regency, Bali. The regression coefficient value (X3) which has positive value indicates that responsiveness has positive and significant effect on guest's satisfaction in the village of Kalibukbuk, Buleleng regency, Bali. The regression coefficient value (X4) which has positive value indicates that the guarantee has positive and significant influence on guest's satisfaction in the village of Kalibukbuk, Buleleng regency, Bali. The regression coefficient value (X5) which has positive value indicates that empathy has positive and significant effect on guest's satisfaction in Kalibukbuk village, Buleleng regency, Bali. Based on the result of data analysis, the results support the hypothesis "Quality of Homestay Services affects level of Guest Satisfaction in Kalibukbuk Village, Buleleng Regency, Bali"

\section{Conclusion}

The results show that service quality variables consisting of physical form, reliability, responsiveness, assurance, and empathy simultaneously had an influence on guest satisfaction in quality of homestay services. Service quality variables partially have positive and significant effect on guest satisfaction in quality of homestay services in Kalibukbuk village, Buleleng Regency, Bali.

\section{References}

[1] M. J. Thomas, "Marketing Management: Analysis, Planning and Control (Book)," J. Bus., 1967.

[2] P. Kotler, Marketing management : analysis, planning, implementation and control. 1997.

[3] B. Irawan, "Konversi lahan sawah : potensi dampak, pola pemanfaatannya, dan faktor determinan," Forum Penelit. Agro Ekon., 2005.

[4] P. Kotler, Marketing Management Millenium Edition. 2000.

[5] A. Sandria, "Pancasila Values In Tradition On The Bali Hindu Community Reviewed From Bali Adat Law And Hindu' s Law," Vidyottama Sanatana Int. J. Hindu Sci. Relig. Stud., vol. 2, no. 2, pp. 226-231, 2018.

[6] P. E. Rahayu Dewi, I. G. Suwindia, and I. K. Sudarsana, "Ethic Educations Of Leadership In Tenganan 
Pegringsingan Traditional Village," Vidyottama Sanatana Int. J. Hindu Sci. Relig. Stud., vol. 2, no. 2, pp. 269-275, 2018.

[7] I. K. Hiroyuki, Akio; Juliawan, I Nengah; Sudarsana, "Internalization Values Of Character Education Towards The Teruna-Daha In The Medi-Median Tradition," Vidyottama Sanatana Int. J. Hindu Sci. Relig. Stud., vol. 2, no. 2, pp. 232-238, 2018.

[8] N. M. A. S. P. Paramitha, "Theological Symbolisation Of Watugunung Myth And Sangkuriang Legend ( Comparative Literature Study )," Vidyottama Sanatana Int. J. Hindu Sci. Relig. Stud., vol. 2, no. 2, pp. 211-217, 2018. 